\title{
Pentingnya Kepuasan Kerja Karyawan Dalam Organisasi
}

\author{
Dona andora \\ Universitas Negeri Padang \\ Indonesia
}

\section{Email: andoradona@yahoo.co.id}

Abstrak- Job satisfaction in any case is very important. The tendency to improve employee performance in a company cannot be achieved without employee job satisfaction. In addition, employees who do not reach the level of job satisfaction will not reach psychological maturity in themselves. They tend to be lazy at work. If employees have behaved that way then it is difficult for a company to achieve its goals.

Keywords: satisfaction, work, employees, organization

\section{Pendahuluan}

Karyawan atau pegawai yang puas dengan apa yang diperolehnya dari perusahaan akan memberikan sesuatu yang lebih untuk perusahaan dan kemudian ia akan berusaha memperbaiki kinerjanya sehingga ia pun terus mendapat kepuasan kerja yang kemudian akan menghasilkan hasil kerja yang maksimal. Perusahaan harus mengenali faktor-faktor yang mampu menghasilkan kepuasan kerja bagi karyawan sehingga perusahaan akan terus maju dan berkembang dan kemudian menjalankan apa yang seharusnya perusahaan lakukan untuk mencapai kepuasan kerja.

Dalam realita yang ada karyawan dan perusahaan adalah dua buah aspek yang tidak dapat dipisahkan satu sama lain karena keduanya sangat berkaitan dalam menjalankan suatu proses di mana keduanya ada di dalamnya. Sebagai contoh suatu perusahaan yang mempunyai produktivitas yang tinggi serta motivasi yang tinggi akan menghasilkan kinerja serta pencapaian tujuan yang menguntungkan perusahaan tersebut, dan jika karyawan perusahaan itu tidak mempunyai produktifitasa dan motivasi yang tinggi tentu akan membawa kemunduran bagi perusahaan bahkan bias membawa kebangkrutan 


\section{I .KAJIAN TEORI DAN PEMBAHASAN}

\section{A. Pengertian kepuasan kerja}

Kepuasan kerja merupakan cara seseorang pekerja merasakan pekerjaannya yang merupakan generalisasi sikap - sikap terhadap pekerjaannya yang didasarkan atas aspek - aspek pekerjaan yang bermacam - macam.

Menurut (Ermita, 2018) Keberhasilan suatu organisasi dalam mencapai tujuan tidak terlepas dari faktor sumber daya manusianya. Istilah sumber daya manusia dapat disamakan artinya dengan pegawai atau karyawan, yaitu orang yang mengerjakan suatu pekerjaan dalam suatu organisasi, baik organisasi yang bergerak dalam bidang pemerintahan maupun bidang swasta. Setiap pegawai dalam organisasi tentunya memiliki tugas dan tanggung jawab yang harus dilaksanakan sesuai dengan tuntutan organisasi atau lembaga. Baik atau buruknya pekerjaan seorang pegawai dapat dilihat dari kinerjanya.

B. Faktor yang mempengaruhi kepuasan kerja

1. Pekerjaan itu sendiri (Work It self)

Setiap pekerjaan memerlukan suatu keterampilan tertentu yang sesuai dengan bidangnya masing-masing. Susah tidaknya suatu pekerjaan itu serta perasaan seseorang bahwa keahliannya dibutuhkan dalam melakukan pekerjaan tersebut, akan berpengaruh terhadap perusahaan yaitu bias jadi meningkatkan atau mengurangi kepuasan kerja.

2. Atasan (Supervision)

Seorang atasan yang baik berarti ia harusa mau menghargai pekerjaan bawahannya sendiri. Bagi bawahan, atasan bisa dianggap sebagai figur ayah /ibu /teman /rekan kerja dan sekaligus sebagai atasannya.

3. Teman sekerja (Workers)

Merupakan faktor yang sangat berhubungan erat dengan hubungan antara pegawai dengan atasannya dan dengan pegawai lain, baik yang sama maupun yang berbeda jenis pekerjaannya. Bagaimana hubungan yang terjalin akan mempengaruhi kepuasan kerja.

4. Promosi (Promotion)

Merupakan faktor yang berhubungan dengan ada tidaknya kesempatan untuk memperoleh peningkatan karier selama bekerja dalam sebuah perusahaan.

5. Upah (Pay)

Merupakan faktor pemenuhan kebutuhan hidup pegawai yang dianggap layak atau tidak dalam memenuhi kebutuhan sehari - hari hidupnya.

6. Kedudukan (posisi)

Umumnya seseorang yang bekerja pada pekerjaan yang lebih tinggi akan merasa lebih puas daripada karyawan yang bekerja pada pekerjaan yang lebih rendah. 


\section{Pangkat (golongan)}

Pada pekerjaan yang mendasarkan perbedaan tingkat (golongan), sehingga pekerjaan tersebut memberikan kedudukan tertentu pada orang yang melakukannya. Apabila ada kenaikan upah, maka sedikit banyaknya akan dianggap sebagai kenaikan pangkat, dan kebanggaan terhadap kedudukan yang baru itu akan merubah perilaku dan perasaannya.

\section{Umur}

Dinyatakan bahwa ada hubungan antara kepuasan kerja dengan umur karyawan. Umur di antara 25 tahun sampai 34 tahun dan umur 40 sampai 45 tahun adalah merupakan umur-umur yang bisa menimbulkan perasaan kurang puas terhadap pekerjaan yang ia jalani.

C. Peran manajer dalam kepuasan kerja

Kepuasan kerja pada dasarnya merupakan hal yang bersifat sangat individual. Setiap individu staff memiliki tingkat kepuasan yang berbeda-beda sesuai dengan keinginan dan sistem nilai yang dianutnya. Semakin banyak aspek dalam pekerjaannya yang sesuai dengan keinginan dan sistem nilai yang dianut individu, semakin tinggi tingkat kepuasan yang didapat. Dalam konteks meningkatkan kepuasan kerja, maka seorang manajer dituntut untuk memberikan suasana kerja yang baik dan menyenangkan, adanya jaminan/keselamatan kerja sehingga karyawan akan merasa terpuaskan. Secara empirik, ada hubungan antara kepuasan kerja dengan produktivitas.

\section{Pembahasan}

Kesuksesan dalam suatu organisasi tergantung kepada orang - orang yang ada di dalamnya. Jika orang - orangnya yang bekerja di dalamnya berkinerja bagus, maka kinerja organisasi tersebut juga akan bagus. Karyawan dengan kepuasan kerja yang tinggi cenderung akan lebih memiliki kepedulian terhadap organisasi yang ia ada di dalamnya. Sehingga mereka akan memberikan nilai yang superior kepada para pelanggan melalui layanan terbaik yang bias dilakukan. Mereka juga cenderung lebih memiliki komitmen tinggi terhadap organisasi. Sehingga organisasi yang kepuasan kerja karyawannya tinggi akan memiliki perkembangan yang tinggi dan cepat pula dan tidak banyak kemunduran yang terjadi. Kemudian, karyawan dengan kepuasan kerja tinggi juga lebih produktif yang tidak hanya berdampak pada meningkatnya produktivitas individual, tentunya hal ini juga berdampak positif pada produktivitas organisasi atau perusahaan. Sehingga pada jangka panjang, kinerja perusahaan juga makin baik dan meningkat. 
Hubungan antara kepuasan kerja dengan variabel lain dapat bersifat positif atau negatif. Kekuatan hubungan mempunyai rentang dari lemah dampai kuat. Menurut Kreitner dan Kinicki (2001;226) Hubungan yang kuat menunjukkan bahwa atasan dapat mempengaruhi dengan signifikan variabel lainnya dengan meningkatkan kepuasan kerja. Beberapa korelasi kepuasan kerja sebagai berikut :

\section{1) Motivasi}

Antara motivasi dan kepuasan kerja terdapat hubungan yang positif dan signifikan. Karena kepuasan dengan pengawasan/supervisi juga mempunyai korelasi signifikan dengan motivasi, atasan/manajer disarankan mempertimbangkan bagaimana perilaku mereka mempengaruhi kepuasan pekerja sehingga mereka secara potensial dapat meningkatkan motivasi pekerja melalui berbagai usaha untuk meningkatkan kepuasan kerja.

\section{2) Pelibatan Kerja}

Hal ini menunjukkan kenyataan dimana individu secara pribadi dilibatkan dengan peran kerjanya. Karena pelibatan kerja mempunyai hubungan dengan kepuasan kerja, dan peran atasan/manajer perlu didorong memperkuat lingkungan kerja yang memuaskan untuk meningkatkan keterlibatan kerja pekerja.
3) Organizational commitment Mencerminkan tingkatan dimana individu mengidentifikasi dengan perusahaan dan mempunyai komitmen terhadap tujuannya. Antara komitmen organisasi dengan kepuasan terdapat hubungan yang siknifikan dan kuat, karena meningkatnya kepuasan kerja akan menimbulkan tingkat komitmen yang lebih tinggi. Selanjutnya komitmen yang lebih tinggi dapat meningkatkan produktivitas kerja.

4) Ketidakhadiran (Absenteisme)

Antara ketidakhadiran dan kepuasan terdapat korelasi negatif yang kuat. Dengan kata lain apabila kepuasan meningkat, ketidakhadiran akan turun.

5) Perasaan stres

Antara perasaan stres dengan kepuasan kerja menunjukkan hubungan negatif dimana dengan meningkatnya kepuasan kerja akan mengurangi dampak negatif stres.

6) Prestasi kerja/kinerja

Terdapat hubungan positif rendah antara kepuasan dan prestasi kerja. Dikatakan kepuasan kerja menyebabkan peningkatan kinerja sehingga pekerja yang puas akan lebih produktif. Di sisi lain terjadi kepuasan kerja disebabkan oleh adanya kinerja atau prestasi kerja sehingga 
pekerja yang lebih produktif akan mendapatkan kepuasan.

\section{III . KESIMPULAN}

Kepuasan kerja itu penting dipelajari dalam kajian perilaku organisasi, karena dengan mengetahui kepuasan kerja maka akan memudahkan bagi organisasi untuk mengembangkan organisasinya tersebut.

Kepuasan kerja merupakan sebentuk rasa senang terhadap apa yang telah dikerjakannya, namun kepuasan kerja bersifat subjektif. Kepuasan antara individu satu dengan individu lainnya cenderung berbeda, karena setiap individu mempunyai kriteria kepuasan tersendiri dalam mengukur tingkat kepuasan hidupnya, namun kepuasan pegaawai dalam bekerja dapat dilihat dari bagaimana kinerja pegawai tersebut namun hal tersebut tidak menjamin pegawai merasa puas karena pada hakikatnya manusia tidak mempunyai rasa puas.

Kepuasan kerja (job satisfaction) mengacu pada keseluruhan sikap yang akan terjadi pada diri setiap individu secara umum terhadap pekerjaannya. Duserick, Frank.2007. The Impact of Effective Faktor-faktor yang dapat mempengaruhi kepuasan kerja di antaranya kondisi kerja/lingkungan kerja, peraturan atau budaya organisasi serta karakteristik organisasi, kompensasi yang memuaskan, Hariandja, Marihot T. E. 2005. Manajemen efisiensi kerja dan partner kerja.

\section{Daftar pustaka}

N, we xley Kenneth dkk. 2003. Perilaku Organisasi dan Pesikologi Personalia. Jakarta: PT Rineka Cipta

P, Ro bbin Stephen. 2002. Prinsip prinsip Perilaku Organisasi ( edisi kelima). Jakarta: Erlangga.

Vavis keith dan W Newstrom. 1985. Perilaku dalam Organisasi( jilid 1 edisi ketujuh). Jakarta: Erlangga.

A artram, Timothy and Gian Casimir. 2007. The Relationship Between Ladersh ip and Follower In-

Role Performance and Satisfaction with The Leader: The mediating Effects of Empowerment and Trust in The Leader. Leadership\&Organi zation Development Journal. Vol.28, No.1.pp: 4-19. Strategic Planning and Leadership on Employee Satisfaction. Competition

Forum. Vol.5, No.1.pp:243-252 
pengembangan, Pengkompensasian, dan Peningkaan produktivitas

Pegawai. Cetakan Ketiga. Jakarta : PT. Grasindo.

Ivancevich, John, M, Konopaske, \& Matteson. 2008. Perilaku dan Manajemen Organisasi. Jakarta : Erlangga.

Kuswadi. 2004. Cara Mengukur Kepuasan Kerja Karyawan. Jakarta: PT ElexMedia Komputindo

Kreitner dan Kinicki. 2005. Perilaku Organisasi. Jakarta:Salemba Empa Ermita. (2018). No PEMBINAAN KINERJA PEGAWAI OLEH PIMPINAN ATASAN LANGSUNG DI KANTOR KEMENTERIAN AGAMA KOTA BUKITTINGGI. 8(2), 8. Retrieved from http://ejournal.unp.ac.id/index.php/bahana/ article/view/105743 